\title{
DETEKSI DINI DAN PENCEGAHAN PENYAKIT DEGENERATIF PADA MASYARAKAT WILAYAH MUTIARA HOME CARE
}

\author{
Amila $^{1}$, Evarina Sembiring ${ }^{2}$, Novita Aryani ${ }^{3}$ \\ 1,2,3 Universitas Sari Mutiara Indonesia \\ Email: mila_difa@yahoo.co.id
}

\begin{abstract}
ABSTRAK
Penyakit degeneratif merupakan penyakit kronik menahun yang banyak mempengaruhi kualitas hidup serta produktivitas seseorang. Umumnya masyarakat baru memeriksakan diri setelah timbul gejala, padahal deteksi dini penyakit penting dilakukan. Tujuan kegiatan pengabdian kepada masyarakat ini adalah untuk upaya preventif dan meningkatkan pengetahuan tentang deteksi dini gejala, komplikasi, pencegahan, dan terapi penyakit degeneratif khususnya penyakit hipertensi, DM, aterosklerosis, osteoporosis kepada masyarakat di sekitar Klinik Mutiara Homecare Kelurahan Dwikora. Pengabdian masyarakat ini terdiri dari 2 kegiatan utama, yaitu pemeriksaan indeks massa tubuh, tekanan darah, gula darah, asam urat dan kolesterol dan pendidikan kesehatan bagi masyarakat tentang penyakit degeneratif. Hasil kegiatan didapatkan bahwa mayoritas memiliki tekanan darah sistolik $<130 \mathrm{mmHg}$ sebesar $60 \%$ dan tekanan darah diastolik < 90 mmHg sebesar 58\%, memiliki Indeks Massa Tubuh (IMT) 25$29,9 \mathrm{~kg} / \mathrm{m}^{2}$ (obesitas) sebesar $32 \%$, kadar asam urat normal sebesar $66 \%$, gula darah sewaktu $<140 \mathrm{mg} / \mathrm{dL}$ sebesar $86 \%$, kolesterol total $>200 \mathrm{mg} / \mathrm{dL}$ sebesar $60 \%$. Peningkatan kualitas kesehatan perlu dilakukan dengan membangun kesadaran dan peningkatan edukasi serta melakukan kontrol kesehatan secara teratur ke pusat kesehatan terdekat.
\end{abstract}

Kata Kunci : Penyakit degeneratif, asam urat, gula darah, IMT, kolesterol

\section{ABSTRACT}

Degenerative disease is a chronic disease that affects the quality of life and productivity of a person. In general, people only have to check themselves after symptoms occur, even though early disease detection is important. The purpose of community service activites is preventive effort and increase knowledge about early detection of symptom, complication, prevention and treatment of degenerative diseases especially hypertension, DM, atherosclerosis and osteoporosis to the community around Mutiara Home Care Clinic, Dwikora Village. This community service consists of 2 main activites, namely examination of body mass index (BMI, blood pressure, blood sugar, uric acid and cholesterol and public health education about degenerative diseases. The results of this community service activites were majority had systolic blood pressure of $<130$ $\mathrm{mmHg}(60,0 \%)$ and diastolic blood pressure of $<90 \mathrm{mmHg}(58 \%), \mathrm{BMI}$ of $25-29,9$ $\mathrm{kg} / \mathrm{m}^{2}$ (obesity) as many as 32\%, normal uric acid levels (66\%), blood sugar at one time $<140 \mathrm{mg} / \mathrm{dL}$ (86\%), total cholesterol > $200 \mathrm{mg} / \mathrm{dL}$ (60\%) The increase of the quality of health needs to be done by building awareness and increased education to community and control to the nearest health center.

Keywords : degenerative disease, uric acid, blood sugar levels, BMI, cholesterol 


\section{PENDAHULUAN}

Saat ini di negara berkembang telah terjadi pergeseran penyebab kematian utama yaitu dari penyakit menular ke penyakit tidak menular. Kecenderungan transisi ini dipengaruhi oleh adanya berubahnya gaya hidup, urbanisasi dan globalisasi (Utomo, 2012; Budiono, 2009; Jose, 2007).

Penyakit degeneratif merupakan kondisi kesehatan dimana organ atau jaringan terkait keadaan yang terus menurun seiring waktu Penyakit ini terjadi karena adanya perubahan perubahan pada sel-sel tubuh yang akhirnya mempengaruhi fungsi organ secara menyeluruh. Penyakit degeneratif semakin berkembang karena menurunnya aktivitas fisik, gaya hidup dan pola makan (Swari, 2020).

Penyakit degeneratif ini tanpa disadari masyarakat sudah dapat dimulai sejak usia produktif dan masyarakat baru memeriksakan diri setelah timbul gejala. Pola hidup dengan diet tinggi lemak (makanan cepat saji) dan tingkat stressor tinggi mempunyai kontribusi positif terhadap timbulnya penyakit degenerative (Khumaeroh, 2016).

Penyakit Tidak Menular (PTM) sebagian besar merupakan penyakit degeneratif yang berkait dengan proses penuaan. Beberapa dari penyakit tidak menular tersebut antara lain, diabetes mellitus, hipertensi, penyakit jantung dan stroke. Penyakit-penyakit tersebut secara disebabkan oleh dua faktor yaitu faktor risiko yang tidak dapat diubah dan faktor risiko yang dapat diubah. Faktor risiko yang tidak dapat diubah misalnya jenis kelamin, umur, dan faktor genetik. Faktor risiko yang dapat diubah misalnya kebiasaan merokok, pekerjaan, aktivitas fisik, kebiasaan merokok, konsumsi alkohol, Indeks Masa Tubuh, lingkar pinggang (Boehme et al., 2017).

Badan Kesehatan Dunia (WHO) memperkirakan, tahun 2020 Penyakit Tidak Menular (PTM) menyebabkan 73\% kematian dan 60\% seluruh kesakitan di dunia. Meningkatkan prevelensi penyakit degeneratif di beberapa negara berkembang akibat peningkatan kemakmuran di negara bersangkutan akhirakhir ini banyak disoroti. Peningkatan perkapita dan perkembangan gaya hidup terutama di kota-kota besar, menyebabkan peningkatan penyakit degeneratif.

Pasien dengan penyakit degeneratif di Indonesia selalu mengalami peningkatan dari tahun ke tahun yaitu pada tahun 2007 sebanyak 9,4\% menjadi 13,3\% pada tahun 2013 (Kementrian Kesehatan, 2018) Di Indonesia angka kejadian penyakit degenerative yaitu stroke sebanyak 1.236.825 orang, penyakit hipertensi sebanyak 84.345 orang, Diabetes Mellitus sebanyak 10 juta orang, penyakit jantung sebanyak 883.447 orang dan penyakit kanker sebanyak 330.000 (Kementrian Kesehatan, 2018). Data Riset Kesehatan Dasar tahun 2013, bahwa prevalensi stroke berdasarkan terdiagnosis tenaga kesehatan di Sumatera Utara didapatkan sebesar $6.6 \%$. Prevalensi stroke cenderung lebih tinggi pada masyarakat dengan pendidikan rendah baik yang didiagnosis nakes $(16,5 \%)$ maupun diagnosis nakes atau gejala $(32,8 \%)$ (Kementerian Kesehatan RI, 2013).

Di wilayah kerja Puskesmas Helvetia, Hipertensi merupakan rangking pertama dari 10 penyakit terbesar yang dilaporkan dengan jumlah 10050 pada tahun 2014. Pada bulan Februari tahun 2015 jumlah pasien hipertensi sebanyak 1077 yang tersebar di dalam 7 kelurahan. Diantaranya Kelurahan Dwikora sebanyak 111 orang, Sei Sikambing (113 orang), Kelurahan Helvetia (125 orang), Kelurahan Helvetia Tengah (432 orang) dan Kelurahan Helvetia Timur (130 orang). Jumlah penyakit hipertensi ini meningkat dari tahun ke tahun. Hipertensi merupakan penyebab terbesar $(80 \%)$ untuk terjadinya 
stroke. Selain itu, faktor risiko lain seperti DM dan jantung menduduki peringkat ke 2 dan 3 setelah penyakit Hipertensi di Puskesmas Helvetia pada tahun 2013, 2014 dan 2015 (Rekam Medis Puskesmas Helvetia, 2015).

Penyakit degeneratif ini dapat mempengaruhi kualitas hidup penderitanya. Pencegahan terhadap penyakit degeneratif ini dapat dilakukan sebelum terdiagnosa maupun sesudah terdiagnosa. Pencegahan yang dapat dilakukan dengan meningkatkan kesadaran akan faktor resiko, menjauhi faktor resiko dan melakukan cek kesehatan secara teratur. Peningkatan kesadaran dapat dilakukan dengan edukasi baik secara langsung maupun menggunakan teknologi. Edukasi dapat meningkatkan motivasi pasien terkait dengan kepatuhan managemen diri (Hallberg et al., 2016). Selain itu dengan menggali riwayat penyakit individu dan keluarga terutama untuk penyakitpenyakit yang sudah diketahui dapat diturunkan.

Permasalahan yang dihadapi mitra adalah kurangnya kesadaran warga kelurahan Dwikora untuk melakukan pemeriksaan berkala tekanan darah, gula darah sewaktu (GDS), pemeriksaan asam urat, kadar kolesterol dan pengecekan indeks masa tubuh (IMT), belum pernah diadakan deteksi dini terhadap hipertensi, penyakit diabetes mellitus dengan pengecekan GDS dan indeks masa tubuh. Hasil observasi ditemukan beberapa warga terdiagnosa diabetus mellitus tetapi tidak diketahui sejak dini, diketahui setelah rawat inap di RS. Kurangnya kesadaran masyarakat akan kesehatan dapat memperburuk kondisi kesehatan mereka dan memicu terjadinya berbagai penyakit kronis seperti diabetes mellitus, hipertensi, hiperurisemia, penyakit jantung.

Skrining DM adalah suatu cara untuk mendeteksi penyakit DM tipe 2 untuk mereka yang tidak mempunyai keluhan. Sekitar 50\% dari pasien DM tidak mempunyai keluhan, maka satu-satunya cara untuk mendeteksi adalah dengan melakukan skrining (Jonathan, 2009). Seseorang dapat diketahui lebih dini bahwa pasien menderita DM melalui skrining DM, sehingga dapat dilakukan upaya pencegahan agar progesivitas penyakit DM tidak berlanjut sampai menimbulkan kecacatan atau kematian.

Tahap awal yang dilakukan bagi penderita hipertensi adalah pemeriksaan tekanan darah. Penyebab hipertensi antara lain faktor keturunan, gaya hidup, pola makan, obesitas, konsumsi garam yang berlebih, merokok dan konsumsi alcohol (Nuraini, 2015). Hipertensi dapat menimbulkan komplikasi seperti stroke, gagal ginjal, gagal jantung (Amila, Sinaga \& Sembiring, 2018).

Hiperurisemia adalah peningkatan kadar asam urat di dalam darah. Keadaan hiperurisemia ini dapat menyebabkan terjadinya arthritis gout yaitu peradangan pada sendi yang disebabkan penimbunan asam urat (Jaliana \& Suhadi, 2018). Keadaan arthritis gout ini dapat mengganggu aktivitas seseorang sehinggga dapat menurunkan produktivitas kerja .

\section{MASALAH}

Alasan kami memilih tempat kegiatan karena Klinik Mutiara Home Care merupakan layanan jasa kesehatan yang didirikan oleh Universitas Sari Mutiara Indonesia pada tahun 2017. Spesifikasi pelayanan yang diberikan oleh Mutiara Home Care adalah kunjungan rumah, pemeriksaan laboratorium, perawatan pasien stroke, perawatan pasien jantung, perawatan luka dan lain-lain. Data yang ada menunjukkan penyakit degeneratif khususnya hipertensi dan diabetes mellitus merupakan kunjungan tertinggi untuk penyakit tidak menular di Mutiara Home Care sejak tahun 2017 sampai 2019. 
Tujuan khusus pengabdian kepada masyarakat ini adalah tercapainya upaya preventif terhadap resiko terjadinya penyakit degeneratif dan resiko komplikasi pada masyarakat. Manfaat kegiatan ini diharapkan dapat meningkatkan pengetahuan tentang gejala, komplikasi, pencegahan dan perawatan penyakit degenerative. Disamping itu masyarakat dapat mengetahui apakah pasien berisiko mengalami penyakit degeneratif melalui pemeriksaan tekanan darah, indeks massa tubuh, glukosa darah, kadar asam urat dan kolesterol, sehingga masyarakat dapat melakukan upaya promotif, preventif untuk mencegah komplikasi penyakit dan mengontrol kesehatannya dengan baik.

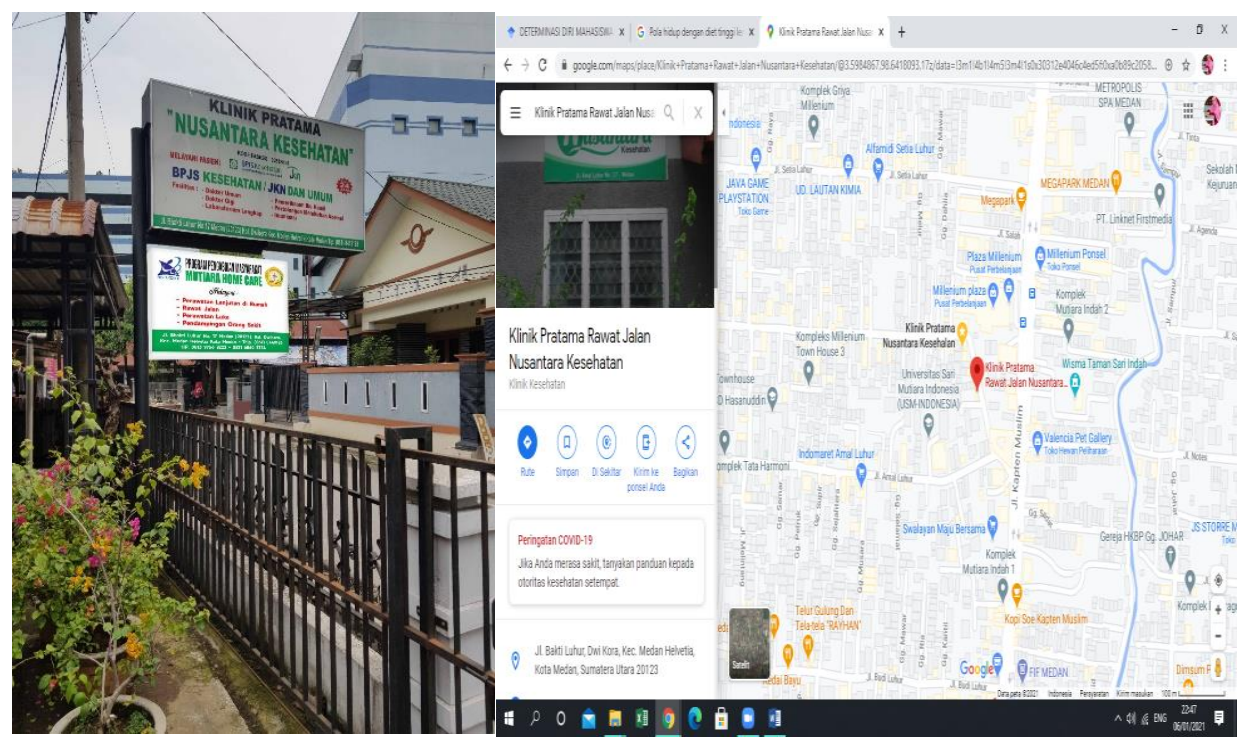

Gambar 2.1 Peta Lokasi Kegiatan Pengabdian Masyarakat

\section{METODE}

a. Tujuan Persiapan

Tahap persiapan dari kegiatan adalah pembuatan pre planning, persiapan pemberian pendidikan kesehatan,pemeriksaan indeks massa tubuh, pemeriksaan tekanan darah, gula darah, kolestrol dan asam urat di Klinik Mutiara Home Care Kelurahan Dwikora Kecamatan Helvetia Medan pada Hari Kamis tanggal 25 Juli 2019.

b. Tahap Pelaksanaan

Sasaran utama dalam kegiatan pengabdian kepada masyarakat ini adalah masyarakat sekitar klinik Mutiara Home Care Kelurahan Dwikora, baik kelompok remaja, dewasa dan usia lansia.

Pelaksanaan kegiatan meliputi :

1) Memberikan pendidikan kesehatan kepada warga terkait penyakit degeneratif yaitu penyakit hipertensi, aterosklerosis, stroke dan osteoporosis. Target kegiatan ini adalah 50 peserta. Pada pendidikan kesehatan pertama, kegiatan ini berupa pemberian informasi dalam bentuk pendidikan kesehatan oleh perawat menggunakan LCD dan power point selama kurang lebih 30 menit dan diikuti sesi tanya jawab selama 15 menit. Pendidikan kesehatan diarahkan untuk membantu pasien dan keluarganya melakukan perawatan diri terhadap keluarga 
sendiri dan bertanggung jawab terhadap kesehatan mereka sendiri. Pendidikan kesehatan ini dapat mencakup beberapa bidang, termasuk promosi kesehatan dan pencegahan penyakit, masalah kesakitan/disabilitas dan dampaknya pada klien dan keluarga.

2) Pemeriksaan indeks massa tubuh (Tinggi badan dan Berat badan) menggunakan timbangan berat badan digital dan pengukur tinggi badan.

3) Pemeriksaan tekanan darah, gula darah, kolestrol dan asam urat. Pemeriksaan tekanan darah dilakukan dengan tensimeter air raksa. Pemeriksaan gula darah, asam urat dan kolesterol menggunakan alat cek gula darah, kolesterol dan asam urat digital. Target peserta ini adalah 50 orang. Pemeriksaan tekanan darah, gula darah sewaktu, kolesterol dan asam urat dilakukan oleh perawat. Pengambilan gula darah, kolesterol total dan asam urat dilakukan dengan mengambil darah tepi pada ujung jari. Darah dimasukkan ke dalam strip test kemudian ditunggu beberapa detik, sehingga hasil terbaca oleh alat. Data tekanan darah, gula darah, kolesterol dan asam urat yang terbaca dicatat dalam form yang sudah disediakan

\section{c. Evaluasi}

Pengumpulan data dilakukan dengan mengisi hasil pemeriksaan pada saat warga melakukan kunjungan kegiatan pengabdian kepada masyarakat di Klnik Mutiara Home Care meliputi usia, jenis kelamin, berat badan, tinggi badan, tekanan darah, kadar gula darah sewaktu, kolesterol, asam urat. Indikator keberhasilan kegiatan dilihat dari jumlah peserta yang hadir lebih dari $50 \%$ dari jumlah undangan dan proses pelaksanaan kegiatan pengabdian.

\section{HASIL DAN PEMBAHASAN}

Kegiatan pengabdian diikuti oleh remaja sampai lansia dan kader kesehatan Universitas Sari Mutiara Indonesia. Antusias peserta dalam kegiatan ini sangat tinggi dibuktikan dengan jumlah kehadiran sebanyak 50 orang peserta dari 80 orang yang diundang. Kegiatan berlangsung dengan lancar, dibuka oleh sambutan dari Ketua Home Care. Selanjutnya peserta menimbang berat badan, tinggi badan, tekanan darah, diberikan materi edukasi, dilakukan pemeriksaan kadar gula darah, kolesterol dan kadar asam urat dan diberikan penjelasan terkait hasil pemeriksaan.
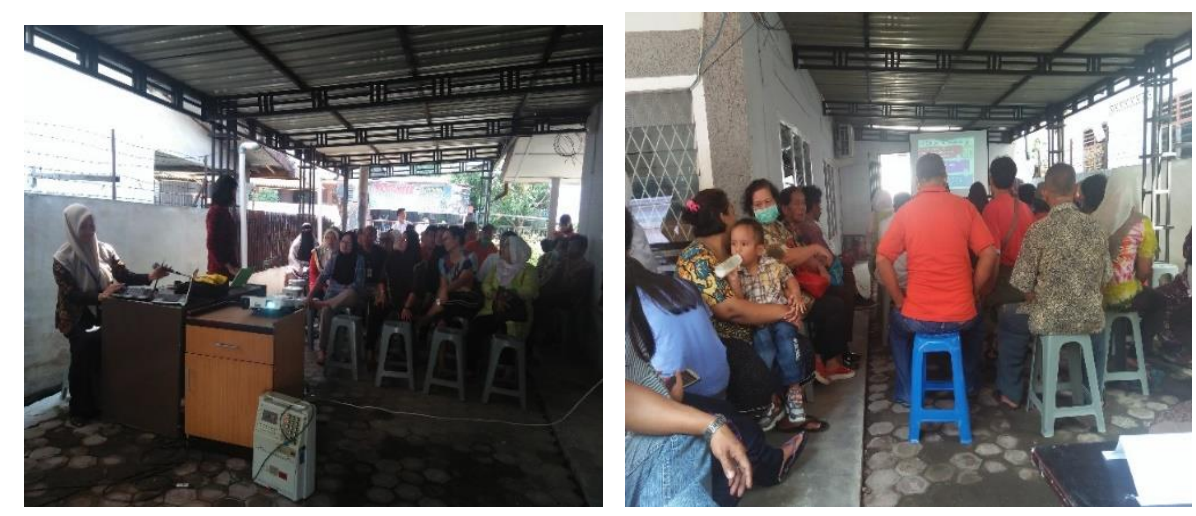

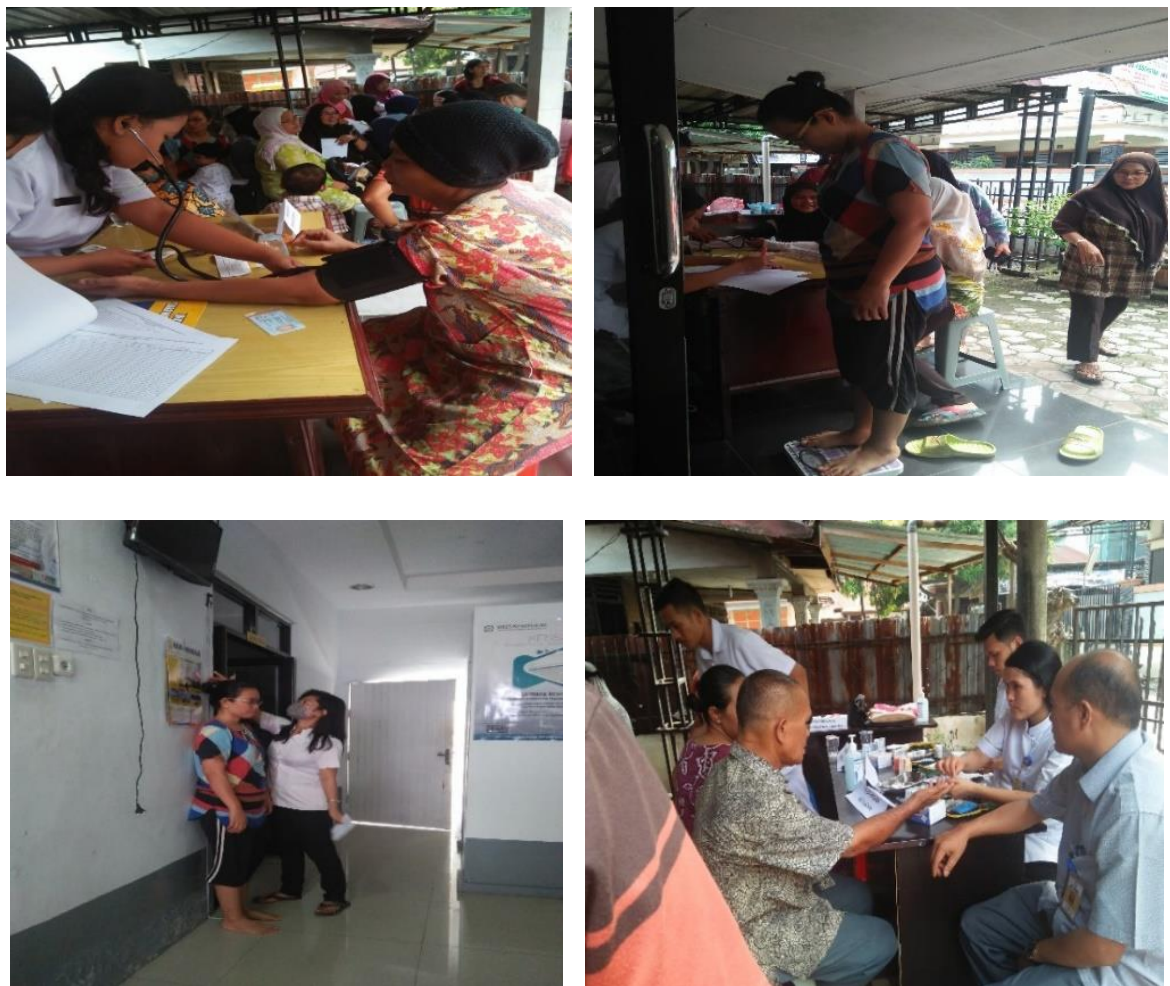

Gambar 1. Penyuluhan kesehatan, pemeriksaan tekanan Darah, IMT, gula darah, asam urat dan kolesterol

Tabel 1. Karakteristik responden berdasarkan hasil pemeriksaan Tekanan Darah, IMT, Asam Urat, GDS, Kolesterol Total $(n=50)$

\begin{tabular}{lcc}
\hline Karakteristik responden & F & $\%$ \\
& & \\
\hline Tekanan Darah Sistolik & 30 & 60,0 \\
$<130 \mathrm{mmHg}$ & 20 & 40,0 \\
$>130 \mathrm{mmHg}$ & & \\
Tekanan Darah Diastolik & 29 & 58,0 \\
$<90 \mathrm{mmHg}$ & 21 & 42,0 \\
$>90 \mathrm{mmHg}$ & & \\
\hline Indeks Massa Tubuh & 3 & 6,0 \\
$<18,5 \mathrm{~kg} / \mathrm{m}^{2}$ & 11 & 22,0 \\
$18,5-22,9 \mathrm{~kg} / \mathrm{m}^{2}$ & 5 & 10,0 \\
$23-24,9 \mathrm{~kg} / \mathrm{m}^{2}$ & 16 & 32,0 \\
$25-29,9 \mathrm{~kg} / \mathrm{m}^{2}$ & 15 & 30,0 \\
$\geq 30 \mathrm{~kg} / \mathrm{m}^{2}$ & & \\
\hline Asam Urat & 33 & 66,0 \\
Normal & 17 & 34,0 \\
Tinggi & & \\
\hline Gula Darah Sewaktu & 43 & 86,0 \\
$<140 \mathrm{mg} / \mathrm{dL}$ & 6 & 12,0 \\
$141-200 \mathrm{mg} / \mathrm{dL}$ & 1 & 2,0 \\
$>200 \mathrm{mg} / \mathrm{dL}$ & & 40,0 \\
\hline Kolesterol Total & 20 & 60,0 \\
\hline$<200 \mathrm{mg} / \mathrm{dL}$ & 30 & \\
$>200 \mathrm{mg} / \mathrm{dL}$ & &
\end{tabular}




\section{a. Tekanan Darah}

Hasil pemeriksaan menunjukkan tekanan darah sistolik $<130 \mathrm{mmHg}$ mayoritas berjumlah 60\% (30 orang) dan tekanan darah diastolik $<90 \mathrm{mmHg}$ mayoritas berjumlah 42\% (29 orang). Peningkatan tekanan darah merupakan suatu keadaan dimana tekanan darah meningkat melebihi tekanan darah normal. Panduan dari AHA mengatakan individu dikatakan mengalami hipertensi jika tekanan systole $>130 \mathrm{mmHg}$ dan diastole $>90 \mathrm{mmHg}$ (Whelton, 2017). Penyebab tekanan darah meningkat diantaranya peningkatan kecepatan denyutan jantung, peningkatan resistensi pembuluh darah tepi dan peningkatan volume darah. Faktor gizi berhubungan dengan terjadinya hipertensi melalui beberapa mekanisme. Faktor usia juga berperan, karena pada usia lanjut pembuluh darah cenderung menjadi kaku dan elastisitasnya berkurang (Sudoyo dkk, 2006).

Beberapa peserta kegiatan yang mengalami hipertensi mengatakan sudah tahu jika tekanan darahnya tinggi, namun masih tidak mematuhi obat. Penyakit degeneratif seperti hipertensi dan diabetes mellitus merupakan silent killer. Program kegiatan pengabdian kepada masyarakat yang telah dilakukan menunjukkan jika lebih dari $50 \%$ peserta mengalami hipertensi dan banyak peserta yang tidak menyadari jika tekanan darahnya melebihi normal karena tidak memahami gejala dari hipertensi. Selain itu beberapa yang sudah mengetahui jika menderita hipertensi masih belum melakukan penatalaksanaan dengan tepat. Untuk itu diperlukan upaya peningkatan kepatuhan terhadap penatalaksanaan baik hipertensi maupun diabetes mellitus.

Prehipertensi dan hipertensi berhubungan dengan berbagai komplikasi pada hampir seluruh organ, tetapi sering diabaikan oleh dewasa muda. Perlu dilakukan intervensi sejak dini untuk mencegah penyakit yang lebih lanjut dengan memodifikasi gaya hidup karena tekanan darah berhubungan dengan faktor risiko yang dapat dirubah, seperti IMT dan aktivitas total (Widjaja, dkk, 2013).

\section{b. Indeks Massa Tubuh}

Hasil pemeriksaan menunjukkan bahwa mayoritas memiliki indeks massa tubuh 25-29,9 kg/m² (kategori obesitas sedang) sebesar 32\% (16 0rang). Indeks Massa Tubuh merupakan metode yang digunakan untuk menentukan status gizi seseorang (Sudoyo, dkk, 2008). Penentuan status gizi yang digunakan adalah pembagian berat badan dalam $\mathrm{kg}$ dengan tinggi badan dalam meter kuadrat dinyatakan dalam indeks massa tubuh atau IMT.

Berdasarkan klasifikasi Indeks Massa Tubuh (IMT) menurut kriteria Asia Pasifik, seseorang dikatakan overweight jika memiliki IMT 23-24,9 dan seseorang dikatakan obesitas jika memiliki IMT $\geq 25$. Sedangkan menurut Depkes RI, Seseorang dikategorikan overweight jika BMI > 25 dan obesitas jika BMI > 27. (Kemenkes RI, 2013). Data dari Riskesdas Depkes RI tahun 2013, menunjukkan bahwa prevalensi obesitas pada kelompok umur dewasa sebesar $15,4 \%$ dan overweight sebesar $13,5 \%$. Jika prevalensi obesitas dan overweight digabungkan, maka prevalensi penduduk Indonesia yang mengalami kelebihan berat badan sebesar 28,9\% (Kemenkes RI,2013).

Peningkatan prevalensi masyarakat yang mengalami overweight dan obesitas disebabkan oleh perubahan gaya hidup masyarakat yaitu asupan energi yang berlebih dan aktivitas fisik yang kurang. Overweight dan obesitas terjadi karena ketidak seimbangan antara energi yang dikonsumsi dengan yang dikeluarkan. Saat ini masyarakat lebih banyak mengkonsumsi makanan 
yang kaya energi seperti lemak dan gula, sedangkan aktivitas fisik rendah karena perubahan moda transportasi dan tuntutan dari pekerjaan (Budiyanto, A K. 2002).

Peningkatan lemak tubuh hingga mencapai kondisi obesitas mampu meningkatkan resiko terjadinya suatu penyakit. Secara umum, baik pada pria maupun pada wanita, meningkatnya lemak tubuh hingga obesitas akan meningkatkan resiko terjadinya hipertensi, hiperlipidemia, ateroskerosis, jantung koroner, diabetes tipe 2 (ASCM, 2013).

\section{c. Kadar Glukosa Darah Sewaktu}

Hasil pemeriksaan menunjukkan kadar gula darah sewaktu $<140 \mathrm{mg} \%$ sebesar 86\% (43 orang). Glukosa merupakan salah satu bentuk hasil metabolisme karbohidrat yang berfungsi sebagai sumber energi utama yang dikontrol oleh insulin. Tes gula darah adalah suatu bagian yang penting dari pengawasan gula darah. Dalam keadaan post absorbsi konsentrasi glukosa darah manusia berkisar antara 80-100 mg/dl. Setelah makan karbohidrat, kadar dapat meningkat sampai sekitar 120-130 mg/dl. Selama puasa, kadarnya turun sampai sekitar $60-70 \mathrm{mg} / \mathrm{dl}$. Dalam keadaan normal, kadarnya dikontrol dalam batas-batas ini. Mengidentifikasi apakah seseorang mengalami diabetes mellitus adalah dengan pemeriksaan glukosa darah dan tidak dapat ditegakkan hanya atas dasar adanya glukosuria saja (Soegondo, 2011). Peningkatan kadar glukosa darah disebut hiperglikemia.

Saat kegiatan berlangsung, satu peserta mengatakan sudah didiagnosa diabetes mellitus sejak 9 tahun yang lalu, namun terkadang masih sering tidak mematuhi diet sehingga hasil pemeriksaannya GDS $380 \mathrm{mg} / \mathrm{dl}$. Ketidakpatuhan dalam manajemen gaya hidup dan pengobatan merupakan salah satu permasalahan yang cukup serius bagi penderita penyakit kronis misalnya hipertensi dan diabetes mellitus (Burnier, 2019).

Hiperglikemia yang berlangsung lama (kronik) pada Diabetes Melitus akan menyebabkan kerusakan gangguan fungsi, kegagalan berbagai organ, terutama mata, organ, ginjal, saraf, jantung dan pembuluh darah lainnya (Suastika K., et al., 2011).

Diabetes mellitus adalah suatu kondisi medis kronis, yang berarti bahwa walaupun itu dapat dikontrol, dia berlangsung seumur hidup. Dengan berjalannya waktu, diabetes dapat menjurus pada kebutaan, gagal ginjal, dan kerusakan syaraf. Diabetes juga adalah suatu faktor penting dalam mempercepat pengerasan dan penyempitan dari arteri-arteri (atherosclerosis), menjurus pada stroke, penyakit jantung koroner, dan penyakit-penyakit pembuluh darah besar lainnya. Diabetes mellitus salah satu penyakit yang tidak dapat disembuhkan, tetapi dapat dikendalikan dengan cara diet, olahraga dan mengkonsumsi buah dan obat (Perkeni, 2011).

\section{d. Kadar Asam Urat}

Hasil pemeriksaan menunjukkan mayoritas memiliki kadar asam urat kategori normal sebesar 66\% (33 orang) dan sisanya sebesar 34\% (17 orang) memiliki kadar asam urat tinggi. Pemantauan kadar asam urat dapat dilakukan dengan tes melalui darah. Kadar normalnya adalah 2.6 hingga 6 $\mathrm{mg} / \mathrm{dl}$ untuk wanita dan 3.5 hingga $7,2 \mathrm{mg} / \mathrm{dl}$ untuk pria. Hasil wawancara dengan 6 orang pasien yang memiliki asam urat yang tinggi, mereka suka memakan jeroan, daging dan makanan laut. 
Penyakit asam urat atau gout adalah sejenis penyakit sendi yang terjadi akibat kadar asam urat yang terlalu tinggi dalam darah. Penyakit asam urat sering dialami oleh banyak orang sekarang ini. Bahkan, orang yang masih tergolong muda juga sering ditimpa penyakit ini. Pada kondisi normal, asam urat larut dalam darah dan keluar melalui urine. Tetapi dalam kondisi tertentu, tubuh dapat menghasilkan asam urat dalam jumlah berlebih atau mengalami gangguan dalam membuang kelebihan asam urat, sehingga asam urat menumpuk dalam tubuh, (Putra, 2007).

Asam urat adalah sisa metabolisme zat purin yang berasal dari makanan yang kita konsumsi. Ini juga merupakan hasil samping dari pemecahan sel dalam darah. Purin sendiri adalah zat yang terdapat dalam setiap bahan makanan yang berasal dari tubuh makhluk hidup. Berbagai sayuran dan buahbuahan juga terdapat purin. Purin juga dihasilkan dari hasil perusakan selsel tubuh yang terjadi secara normal atau karena penyakit tertentu. Asam urat yang berlebih selanjutnya akan terkumpul pada persendian sehingga menyebabkan rasa nyeri atau bengkak, kesemutan dan linu, sendi yang terkena asam urat terlihat bengkak, kemerahan, panas dan nyeri luar biasa pada malam dan pagi.

Faktor risiko yang mempengaruhi tingginya asam urat adalah umur, genetik, asupan purin yang berlebihan, kegemukan, penyakit jantung dan konsumsi obat-obatan tertentu (diuretika) dan gangguan fungsi ginjal. Konsumsi purin yang terdapat dalam daging dan seafood berhubungan terhadap risiko peningkatan kadar asam urat, sedangkan produk susu dapat menurunkan risiko gout dan konsumsi purin dari tumbuh-tumbuhan tidak berpengaruh terhadap risiko gout. Sedangkan konsumsi karbohidrat kompeks seperti nasi, roti, ubi jalar dan ketela dapat memacu pembuangan kelebihan asam urat dalam darah (Lina \& Setiyono, 2014).

\section{e. Kadar kolesterol total}

Hasil pemeriksaan menunjukkan mayoritas kadar kolesterol total $>200$ $\mathrm{mg} / \mathrm{dL}$ sebesar $60 \%$ (30 orang). Berdasarkan hasil wawancara dan pemeriksaan terhadap pasien ditemukan penyebab terjadinya karena cara mengolah makanan yang banyak mengandung lemak dan kurangnya mengkonsumsi buah dan sayuran.

Menurut data kementerian Kesehatan tahun 2014, penyakit jantung koroner merupakan penyebab kematian tertinggi setelah stroke, yakni sebesar $12,9 \%$. Pasien penyakit jantung dan stroke banyak ditemukan pada kelompok usia 45-74 tahun. Namun penyakit ini juga bisa terjadi pada orang berusia 15-24 tahun.

Seseorang disebut memiliki kolesterol tinggi apabila hasil pemeriksaan kolesterol LDL nya lebih dari $190 \mathrm{mg} / \mathrm{dL}$ atau total kolesterolnya lebih dari $240 \mathrm{mg} / \mathrm{dL}$. Hasil pemeriksaan kolesterol yang ideal adalah LDL kurang dari $130 \mathrm{mg} / \mathrm{dL}$, HDL lebih dari $60 \mathrm{mg} / \mathrm{dL}$, kolesterol total kurang dari $200 \mathrm{mg} / \mathrm{dl}$, Trigliserida kurang dari $150 \mathrm{mg} / \mathrm{dL}$

Kolesterol tinggi menjadi faktor pemicu penyakit jantung koroner karena kolesterol tinggi penyebab terjadinya sumbatan di pembuluh arah perifer yang mengurangi suplai darah ke jantung. Kolesterol tinggi juga dapat menjadi pemicu hipertensi dan stroke. Faktor lain yang diduga terkait adalah merokok karena merokok dapat menyebabkan vasokonstriksi otot jantung yang dapat mengurangi kapasitas daya angkut oksigen ke seluruh tubuh 
Berdasarkan hasil pengamatan di lapangan didapatkan kurangnya kesadaran untuk memeriksakan diri secara rutin ke puskesmas terhadap masalah kesehatan dan pengetahuan tentang penyakit degeneratif yang kurang. Hal ini tercermin dari pertanyaan yang diajukan. Setelah kegiatan dilakukan masyarakat memahami bahwa pemeriksaan kesehatan sangat bermanfaat dan penting dilakukan baik dalam keadaan sehat atau sakit untuk mengetahui kesehatan diri sehingga tidak terlambat untuk mencegah dan mengambil tindakan.

\section{KESIMPULAN}

Kegiatan pengabdian kepada masyarakat dapat terlaksana dengan baik dan berhasil.Hal ini ditinjau dari kelancaran acara dan partisipasi dari tim klinik Mutiara Home Care. Masyarakat yang hadir sangat puas dan meminta agar kegiatan penyuluhan kesehatan dan pemeriksaan kolesterol, kadar gula darah, asam urat dapat dilaksanakan secara rutin oleh Mutiara Home care, karena hal ini sangat membantu masyarakat untuk menjaga kesehatan. Setelah kegiatan dilakukan, masyarakat di sekitar Mutiara Home Care pengetahuannya meningkat dan memahami bahwa pemeriksaan kesehatan sangat bermanfaat dan penting dilakukan baik dalam keadaan sehat atau sakit untuk mengetahui kesehatan diri, sehingga tidak terlambat untuk mencegah dan mengambil tindakan.

\section{UCAPAN TERIMA KASIH}

Penulis mengucapkan terima kasih sebesar-besarnya kepada Direktur Pengabdian Masyarakat Kementerian Riset dan Teknologi Pendidikan Tinggi atas hibah yang telah diberikan. Juga kepada Universitas Sari Mutiara Indonesia yang telah memberikan dukungan, fasilitas dan sarana prasarana selama melaksanakan pengabdian kepada masyarakat.

\section{DAFTAR PUSTAKA}

American College of Sports Medicine. (2013). ACSM's guidelines for exercise testing and prescription. Lippincott Williams \& Wilkins.

Amila, A., Sinaga, J., \& Sembiring, E. (2018). Self Efficacy dan Gaya Hidup Pasien Hipertensi. Jurnal Kesehatan, 9(3), 360-365.

Budiyanto, A K. (2002). Gizi dan Kesehatan. Malang. Bayu Media UMM Press.

Budiono, I. (2009). Prevalensi dan Determinan Kejadian Anemia pada Ibu Hamil di Perkampungan Nelayan (Studi Kasus di Kelurahan Mangkang Wetan Semarang). Jurnal KEMAS, 4(2):159-169.

Burnier, M. (2019). Improving blood pressure control in hypertensive population: challenges of low adherence and early discontinuation Hypertension. doi:https: //doi.org/10.1161/HYPERTENSIONAHA.119.12598.

Hallberg, I., Ranerup, A., \& Kjellgren, K. (2016). Supporting the selfmanagement of hypertension: Patients' experiences of using a mobile phone-based system. Journal of Human Hypertension, 30(2), 141-146. doi: 10.1038/jhh.2015.37.

Harahap, J., \& Andayani, L. S. (2018). Pola Penyakit Degeneratif, Tingkat Kepuasan Kesehatan dan Kualitas Hidup pada Lansia (Lanjut Usia) di Kota Medan. In Talenta Conference Series: Tropical Medicine (TM) (Vol. 1, No. 1, pp. 142-149). 
Hartono, A. (2006). Terapi gizi dan diet rumah sakit. EGC.

Jaliana, J., \& Suhadi, S. (2018). faktor-faktor yang berhubungan dengan kejadian asam urat pada usia 20-44 tahun di RSUD Bahteramas Provinsi Sulawesi Tenggara tahun 2017. (Jurnal Ilmiah Mahasiswa Kesehatan Masyarakat), 3(2).

Jonathan, A. (2009). Skrining Diabetes Melitus Di Posbindu Wijaya Kusumah RW 15 Kelurahan Citeureup Kecamatan Cimahi Utara Kota Cimahi Pada Periode Juli 2009 (Doctoral dissertation, Universitas Kristen Maranatha).

Jose R, Banegas. (2007). Relationship between obesity, hypertension and diabetes, and healt-related quality of life among elderly. European Journal of Preventive Cardiology, 14(3):456-462.

Kementerian Kesehatan RI. (2013). Riset Kesehatan Dasar 2013. Jakarta: Kementerian Kesehatan RI. . (2018). Riset Kesehatan Dasar 2018. Jakarta : Kementerian Kesehatan.

Khumaeroh, N. (2016). Determinasi diri mahasiswa pengidap penyakit degeneratif (Doctoral dissertation, Universitas Islam Negeri Maulana Malik Ibrahim).

Nuraini, B. (2015). Risk factors of hypertension. Jurnal Majority, 4(5).

Suastika, K. (2011). Tanya Jawab Seputar Obesitas Dan Diabetes : Memuat Berbagai Pertanyaan Awam Dan Jawaban. Denpasar: Udayana Universitas Press.

Sudoyo, A. W., Setiyohadi, B., Alwi, I., Simadibrata, M., \& Setiati, S. (2006). Buku ajar ilmu penyakit dalam.

Swari, R,C. (2020). Masalah kesehatan pada Lansia. Diakses melalui https: / / hellosehat.com/lansia/masalah-lansia/penyakitdegeneratif/\#gref pada tanggal 11 Februari 2020.

Utomo, M.O., Azam, M. Anggraini, D. N. (2012). Pengaruh Senam Terhadap Kadar Gula Darah Penderita Diabetes, Unnes Journal of Public Health, 1(1):36-40

WHO. The World Health Report (2002). Reducing risks, promoting healthy life. Geneva: WHO.

Widjaja, F. F., Santoso, L. A., Barus, N. R., Pradana, G. A., \& Estetika, C. (2013). Prehypertension and hypertension among young Indonesian adults at a primary health care in a rural area. Medical Journal of Indonesia, 22(1), $39-45$ 